\title{
Rudiments of axiology for sustainable tourism
}

\author{
Agnieszka Klimska ${ }^{1}$, Andrea Klimková2, Marcin Leźnicki ${ }^{3}$ \\ ${ }^{1}$ Institute of Ecology and Bioethicts Cardinal Stefan Wyszyński University in Warsaw, Poland, a.klimska@uksw.edu.pl \\ ${ }^{2}$ Department of Ethics and Applied Ethics Matej Bel University in Banská Bystrica, Slovakia \\ ${ }^{3}$ Institute of Philosophy Nicolaus Copernicus University in Toruń, Poland
}

\begin{abstract}
The present article raises the question of sustainable tourism in Poland and Slovakia, highlighting its significance, as well as its objectives and tasks. The situation of tourism in Poland is presented in relation to the issues of spatial economy, whereas Slovak example concentrates mainly on the importance of cultural heritage. Both interrelated aspects were considered crucial for the development of sustainable tourism. Pointing to the noticeably unsustainable character of modern tourism, the authors emphasized the urgent need to refer to ethical and axiological arguments in the process of implementing the principles of sustainable development and spatial order to tourism.
\end{abstract}

\section{Keywords}

sustainable tourism, axiology, spatial economy, cultural heritage

\section{Introduction}

The concept of sustainable tourism has been developed as part of the idea of sustainable development which consolidates a number of scientific disciplines as well as non-scientific practical activities. Initially, this concept conveyed postulates and principles bearing more affinity to ecotourism ${ }^{1}$,

1 The term ecotourism is usually used to designate any activity or tourism activity oriented towards the shaping of two types of tourist attitudes and behaviors. On the one hand, the ones focused on the direct contact of tourists with the so-called primeval nature, or a natural landscape in protected areas and thus completely excluded from any human interference and intervention. These areas are intended to constitute a place of encounter for man and the "wild nature", which can be admired (as part of aesthetic experience) and contempla- ted (in a kind of meta-reflection) in undisturbed tranquility. On the other hand, ecotourism calls attention to the urgent need to promote pro-ecological attitudes, not limited only to the preservation of peace and quiet in the place where we are and which we visit (observe) but, among others, on adapting the volume of tourist traffic to the tourist capacity of a given area, creating the so-called eco-tourist infrastructure, using materials that are not harmful to the environment, including reusable as well as biodegradable ones and processing them only in places intended for that purpose. In the case of sustainable tourism, attention is paid (as discussed in more detail in the article) to the urgent need to apply sustainable development postulates (principles) to tourism. (Cf.) D. Zaręba, 2006, Ekoturystyka. Wyzwania i nadzieje, Wydawnictwo Naukowe PWN, Warszawa; S. Wearing, J. Neil, 1999, Ecotourism. Impacts, potentials and possibilities, BH; D. A. Fennell, 2008, Ecotourism, Routledge; M. Matlegiewicz, 2009, Ekoturystyka jako 
whereas its present, broader understanding is inscribed in the systemic perception of the socio-economic development. Consequently, sustainable tourism, in its basic form, means implementing the postulates and goals of sustainable development in the tourism economy. In other words, it consist in a strive towards achieving a balance between the needs of tourists as well as those of the natural environment and local communities. At the same time, it will also accommodate the benefits issuing from it for the cultural environment and balance the development and competitiveness of tourist destinations and interested enterprises. $\mathrm{Nu}$ merous documents related to sustainable development provide an outline of the general concept of sustainable tourism. Some of those documents directly formulate specific proposals for activities in the indicated area, while others contain defined guidelines and principles that should be adapted in tourism so that it could gain a more sustainable character. ${ }^{2}$

Similarly, the assumptions of sustainable development are more and more often taken into account in spatial management, or more broadly, in spatial economy. They are included, among others, in spatial planning processes, modernization of urban space and revitalization of degraded areas, or even in relation to recreational areas.

The links between landscape and tourism are undeniable. On the one hand, those interrelationships have an impact on spatial planning and development and, on the other, on the shape of areas attractive for

przyjazna środowisku forma turystyki, in: Folia Pomeranae Universitatis Technologiae Stetinensis. Folia Pomer. Univ. Technol. Stetin; Oeconomica 275 (57), 59-66.

2 One can point, for example, to "A Sustainability Strategy for Tourism" proposed in 1998 by International Friends of Nature (Position paper of the International Friends of Nature on the role of tourism in the context of sustainable development), ed. by Manfred Pils, INF, or "Agenda for Sustainable and Competitive European Tourism" published by the European Committe in 2007. the tourism industry. They are also important for the implementation of the goals issuing from the principles of sustainable development.

As the point of departure, the present article will present the concept of sustainable tourism, followed by examples of its implementation in spatial planning and management practiced in Poland and Slovakia. The main goal of the article is to highlight the importance of axiology in the implementation of sustainable development principles and spatial order in tourism.

\section{Concept of sustainable development}

Scientific literature related to the topic of sustainability abounds in manifold definitions of "sustainable tourism". The very concept was first coined in the 1980s, after the publication the Brundtland Report in 1987. Pertaining to the term "sustainable development" defined in the document, a new understanding of tourism was proposed, namely, one taking into account tourism's multidimensional connections, primarily with the natural environment, society and economy. According to D. Weaver, this is a type of tourism, which poses no threat to the economic, social, cultural or environmental integrity of tourist destinations in a relatively long-term perspective (Weaver 2001: 80). In addition, it takes into account the overall contribution of the current and future (i.e. forecast) environmental and socio-economic factors defining the needs of both visitors and inhabitants of a specific place (Patterson 2016: 5). Such a model of tourism is promoted by the United Nations World Tourism Organization (UNTWO), which assumes that it will have an impact on the economic growth, encourage social inclusion and allow to address the issues of the natural environment resources (Web-o1).

The Global Sustainable Tourism Council (GSTC) points out that tourism may serve as a tool in conservation of the environment and fight against poverty (Web-02). Thus, implementation of sustainable tourism can in practice contribute to improving the quality 
of life of the poorest. For this purpose, UNWTO is implementing the ST-EP (Sustainable Tourism - Eliminating Poverty) program, which is aimed at taking initiatives in the field of tourism to counteract the phenomenon of poverty (Sofield, De Lacy et al. 2004: 1). What is more, this organization is involved in the implementation of the 2030 Sustainable Development Goals, with particular emphasis on the elimination of poverty and on environmental protection. This dimension of sustainable tourism was addressed by one of the items on the agenda of the eleventh meeting of the UNWTO Committee on Tourism and Sustainability, which took place in Madrid on January 17, 2018 (Webo3). Implementation of the goals set out in the Agenda for Sustainable Development 2030 through sustainable tourism means also providing universal access to safe, inclusive and accessible, green and public spaces (goal 11). In addition, developing and implementing tools to monitor the impact of sustainable development on sustainable tourism creating jobs and promoting local culture and products (goal 12). An important task, as emphasized by UNWTO signatories, consists also in activity aimed at raising people's awareness of sustainable development and lifestyle in harmony with nature (Web-O4).

In the opinion of some authors (Niezgoda 2006, Meyer 2008) striving for sustainable development is a key trend in modern tourism. Therefore, it is important to understand it as broadly as possible, i.e. as “(...) encompassing all forms of development, management and tourism activities that sustain the ecological, social and economic integrity of the territories (...)" (Meyer 2008: 213).

When discussing the problem of tourism, including sustainable tourism, it is impossible to ignore the issue of space in which those areas of industry are realized as well as of the process of reduction, which the space is undergoing. Limitation of space leads to increasing social conflicts, also about tourist areas. Space is more and more often perceived as a rare, desirable good, demanding rational management and having not only economic but also intangible value. In this context, sustainable tourism will, and certainly may, serve the purpose of resolving conflicts related to the tourist space, especially between tourism development goals and the need to protect the resources of the social and natural environment.

To sum up, it can be assumed that sustainable tourism in its simplest sense is one that systematically takes into account the goals and principles of sustainable development. In other words, the concept of tourism may be brought down to implementing the postulates or principles of sustainable development in the tourism economy. It is thus, the question of sustainable management of the natural environment in tourism, i.e. management that will take into account economic and socio-cultural goals, as well as health and safety of specific cities and nations (Chan 2010: 25).

The above-presented position acquired a formal character and it was adopted during the "Globe 9o" conference in Vancouver, which was attended by, among others, the contemporary Prime Minister of Norway Gro Harlem Brundtland. During this conference the three key principles for tourism planning and management were formulated (Niezgoda 2008: 87), namely:

- considering tourism by decision-makers as an option of economic development and treating it on a par with other forms of economic activity when making development decisions;

- creating an adequate tourism information base that would allow for a better understanding of tourism's importance as well as its analysis and monitoring in the context of other economic sectors;

- development of tourism in the manner consistent with the principles of sustainable development.

While analyzing the guidelines adopted after the conference, it is impossible to overlook the fact that sustainable tourism is, thus, an example of tourism understood as the possibility of stable and sustainable 
economic development integrating multidimensional economic, socio-cultural (including aesthetic) and historical (including cultural heritage) goals. It also accommodates the needs of the natural environment during its planned reorganization, for example as part of activities undertaken to eliminate the negative effects of human impact on the natural environment and to protect the biodiversity of ecosystems.

\section{Sustainable spatial economy for tourism in Poland}

Spatial economy is currently undergoing dynamic development, due to, among others, the directions of socio-economic development adopted within its framework and the proposed solutions to key socio-economic problems in the area of spatial economy. It constitutes both a field of knowledge and a practical activity. Such inclusion of both theoretical and practical aspects of spatial economy is congruent with its understanding proposed by, among others, J. Dębski. According to the author, this economy should be understood as comprising three aspects, namely:

- practical activity, aimed at introducing spatial order in the existing spatial development while respecting the good of the individual and society in the longest possible time perspective,

- the reality, which consists of the overall phenomena occurring in space,

- science focusing on the study of the past and present state of spatial development of specific areas and striving to find their hidden and complex structures determining the functioning of the whole (Dębski 2001).

Spatial economy is today more often treated as economy in a spatial aspect rather than the theory of economics that takes into account spatial content. It is thus divided into: spatial planning, spatial management and spatial development, and interdependencies at the "design - implementation state of spatial order" point of convergence (Parysek 2006).
Along with the transposition of sustainable development assumptions into a broadly understood economy, the crisis of space began to be emphasized and especially the growing problem related to its planning and development. At the same time, it was noticed that the implementation of sustainable development principles into spatial economy and into the related area of tourism, provides an opportunity to protect space and ensure proper human existence in it by taking into account the features of absolute space (i.e. diversity, resistance and limitations). The aforementioned space crisis is due to, on the one hand, lack of local spatial development plans, failure to adapt them to local strategies or higher-level documents (voivodeship, national) and, on the other, improper human spatial activities and irrational use of natural environmental resources. Both aspects have a clearly negative impact on Polish politics and tourism economy. As noted by M. Kozikowska, the "(...) living conditions of the inhabitants of regions attractive for tourist (among others, due to the size of their income and its sources as well as the level of education) and lack of spatial development plans determine the development of tourism and recreation, which is often done in a chaotic way, is subordinated to short-term goals (especially financial) and rarely refers to the principles of sustainable development" (Kozikowska 2013: 47).

The assumptions of sustainable development that are adopted (at least in theory) as part of spatial planning or development arise, for example, from statutory obligations. According to the Spatial Planning and Development Act of March 27, 2003 (Journal of Laws No. 80, item 717), spatial activities should be conducted in the spirit of sustainable development. Spatial order is the second principle that was referred to in the document. It can be understood as striving to limit the negative effects of improper spatial development. In the abovementioned Act, the issue of spatial order appears alongside the principle of sustainable development. However, it should be clearly emphasized that in the case of landscape, it 
becomes a determinant of sustainable development. In the case of this type of development, it means integrated order understood as "(...) the way of spatial organization and functioning of the socio-economic system, which fulfills the criteria of social rationality and enables proper functioning of the system and preservation of the environment" (Meyer 2008: 60).

Practical implementation of the indicated principles means, for example:

- taking into account the limitation of space and, therefore, its treatment as a common and rare good, possessing its own value;

- occupying space which is valuable from the point of view of its nature and/or culture only in specific (justified) cases;

- taking into account the real capacity of natural and cultural areas when shaping space for specific purposes (including tourism and recreation);

- reclamation of degraded areas;

- undertaking preventive actions, especially in relation to areas particularly exposed to pollution or destruction;

- monitoring spatial behavior taking into account the needs of future landscape users;

- developing spatial ethics and promoting its assumptions.

The above-specified rules are also appropriate for the concept of sustainable tourism, although in practice they are used sporadically, which in turn may indicate a non-effective and inconsistent implementation of a defined (e.g. on a regional level) spatial economy or tourism policy. In fact, when implementing the concept of sustainable tourism, it is necessary to refer it to the actual area with a specific tourist potential and to carry out case studies, in accordance with spatial development plans. It is also necessary to take into account environmental protection requirements, the socio-economic situation of the region, as well as the assumed size of tourist and recreational traffic (Kozikowska 2013: 56).
Some aspirations in the area of sustainable tourism development are contained in the Tourism Development Program until 2020 adopted in 2015, by the Resolution of the Council of Ministers No. 143/2015. This document is a response to the idea of tourism proposed by the European Union, whose priority is to develop a sustainable, high-quality tourism sector. Fostering sustainable economic development in Poland based on tourism is to be carried out by implementing the objectives set out in the above-mentioned Program. These objectives reflect Poland's approach to the development of tourism taking into account environmental protection and sustainable development in congruence with Poland's economic policy. One of the four operational objectives refers directly to spatial economy as aims at developing and modernizing landscape for the development of tourism and tourist infrastructure based on the principles of sustainable development and environmental protection regulations. Specific tasks in this area should consist in, among others, supporting tourist investments within the framework of revitalization programs, urban and rural development, as well as activities for the development of tourist infrastructure (Program Rozwoju Turystyki, 2015: 37-39).

Bearing in mind the principles of sustainable development and spatial order, it is important that the assumptions for the development of tourism until 2020 should not only reflect the program objectives, but each time take into account the arguments and needs of all stakeholders in the economic, social and environmental area.

\section{Sustainable tourism in the context of spatial planning in Slovakia on the example of cultural heritage}

The idea of sustainable tourism points to the creation of a sustainable locality, development of a certain territory and the balance between the three pillars (as shown by the common sustainability index), namely: economic prosperity, nature conservation (ecological values) and the society (cultural 
values, equity, well-being, health, quality of life), i.e. protection of natural and cultural diversity. Sustainable development is, in this respect, a value-balanced inherently present component of both spatial and landscape planning. Sustainable Development, Spatial and Landscape Planning have a common goal, namely, to seek a meaningful and sustainable land use to optimize all the components in the environment, while ensuring the sustainable development and protection of natural and cultural heritage. Nevertheless, both these planning areas are not coordinated in practice in Slovakia. The beneficial effect of tourism, providing it is sustainable and based on good practice, can improve the quality of life, eradicating poverty, preserving the natural and cultural heritage and facilitating the economic emancipation of young people or women. It enhances local traditions as well as natural and cultural values. If it is based on the principle of sustainability, tourism means not only social responsibility and social justice, but also intergenerational justice and elements of biocultural ethics (Rozzi 2013).

Both landscape and spatial planning have a common objective, namely, they seek a meaningful use of landscape so as to optimize all the components in the environment, while ensuring sustainable development and protection of natural and cultural values. However, in practice, these planning areas are not coordinated. For the time being in Slovakia, legal norms are barely congruent and, at some points, they are even contradictory (despite Agenda 21 and the European Landscape Convention). In Slovakia, the two laws - the Nature and Landscape Protection Act and the Building Law (Act no. 50/1976 Coll. on land-use planning; Act no. 543/2002 Coll. on Nature and Landscape Protection) as well as the two policies of regional development and sustainable tourism, should adopt the same and common ethical goal: sustainability and the protection of cultural values. There are several reasons for that, namely, they fundamentally affect landscape management, including its use, protection and planning, and should therefore be complementary. Currently, discussions about their new wording are taking place in Slovakia.

A new element of the Sustainable Tourism Agenda is/can be The Cultural heritage whose potential to contribute to the triad of goals as an important part of the national and regional policies in the area has already been present in the discourse on sustainability. Only in the so called "Post2015 Agenda", the world heritage appears among the sustainability goals and strategies in terms of its value in a specific territory, country, or region. It is based on various contexts of cultural heritage, different demands, and services such as the tradition and historical value of the region, panorama of knowledge and the value base as the space for interaction of man and nature (cultural heritage is closely related to the natural one). Slovak regions, as well as Polish regions, have a unique natural and cultural richness, which makes them a potential attractive tourist destination in the future. Countries are not restricted in enhancing their competitive advantage (Širá 2015) to improve their position through innovative and inventive potential (Dúbravská, Širá 2015). Sustainable tourism as an instrument of regional development is a good practice adopted on the basis of the following principles: economic viability, local prosperity, equality of employment conditions, social equality, meeting the needs of visitors, local control of the planned strategy, cultural diversity, physical integrity, support and protection of biodiversity, efficiency in the use of local resources, environmental protection (UNWTO 2016).

The highly valued places in our world, referred to as the cultural heritage, overlap and intertwine in complicated relationships; they relate to traditions, specific culture, public and collective memories, as well as to the policies of identity and recognition. Cultural heritage is often perceived as an industry. Therefore, it is a subject of not only social, but also ethical inquiries emerging from 
a variety of involved parties into questions such as, whether it is just if cultural heritage generates income for private companies or the state treasury. The initial discourse on the ethics of cultural heritage appeared in the 2oth century addressing the need to create ethical standards for protecting natural the cultural values. According to Paul Ricoeur, our collective future is based on the "social duty to remember that is predicated on the need to fight against the erosion of traces," (Ricoeur 1999: 9).

The New International Development Paradigm of Culture in the Post-2015 Sustainable Development Agenda marks the beginning of the new understanding of cultural heritage. The Agenda offers new horizons: "The 'one size does not fit all' motto places culture at the centre of context-based approaches to sustainable development and improved governance. In what ways does culture act as an enabler and a driver throughout the sustainable development agenda? ... What are the consequences of a Post-2015 Agenda without culture?" (UNESCO, 2015).

Cultural heritage can be perceived as an exclusive concept of sustainable tourism facilitating the creation of identity, solidarity, tradition, good life, prosperity, social justice and also providing the means to reduce poverty and regional disparities. However, cultural heritage is a battlefield of power relations and often even unethical exploitation. Therefore, it is a subject of discussions on social justice and ethical leadership, i.e. the issues of transparency, participation, shared governance as well as claims and rights of the citizens regarding the control of their cultural heritage (Marstine 2011); illegal trade, looting, destruction of certain locations, etc. For these reasons, the challenge is to ensure the compliance with the principles of transparency, justice, responsibility, knowledge, and value sharing not only in monument protection, but in all processes related to the management of cultural heritage in terms of sustainability. The last two decades have witnessed the development of the cultural heritage ethics as a specific type of applied ethics (social ethics). There have even been developed professional codices for professions that serve governing and protecting the world heritage (Ireland, Schofield 2015). Establishing the link between the world heritage and sustainable development may be the future of applied ethics.

Current socio-economic developments, have renewed the interest for the role of regional development and spatial planning, underlining the interactions with socio-economic sustainability, technological change, and socioeconomic development worldwide with social responsibility. The key elements for the sustainable development policy concern the efficient and reasonable use of resources, encouraging the development of new productive technologies (best available technology), extending the use of efficiency enhancement schemes and encouraging both innovative and productive activities and social innovations. Within this framework, development tourism increasingly relies on information and knowledge, and on cultural heritage, which creates value through their ability to manage these valuable assets. The question is of a more pragmatic nature: "how to" set the prospect of the region and sustainable tourism in the context of spatial planning along with the relevant ethical policy and human management in the public administration and regional companies. What ethical instruments should be implemented in the social infrastructure in order to improve sustainable tourism and the unfavourable situation of the region which deserves our protection and support?

\section{Axiology as a tool for implementing sustainable development principles into tourism}

Tourism constitutes an important element of spatial planning and management and, on a wider plane, of the spatial development policy. Nevertheless, due to the rapidly growing tourist traffic and its often unfavorable impact on the population living in tourist 
regions (who undergo, among others, the process of alienation and cultural atomization), as well as to the prevailing lack of balance in the area of tourism (which is accompanied by, for example, the phenomena of tourist traffic overload and tourism commercialization), it is becoming indispensable to make planning decisions which would provide basis for determining the manner of using natural, economic and cultural resources while respecting the needs of local inhabitants.

Effectively, and at the same time responsibly managed space influences the development of sustainable tourism, and at the same time does not disturb the daily functioning of local communities.

In order to work out proper plans for an area that is to serve tourist purposes, it is important to choose its best location, as well as to acquire thorough knowledge of its tourist values, including natural and cultural ones. This is a prerequisite for the assessment of the indicated area's potential to serve tourist purposes and for the estimation of the future tourist traffic, taking into account the principle of sustainable development and spatial order.

Practical development of areas allocated for sustainable tourism can be carried out in various ways. By definition, three indications should be met, i.e. ecological, economic and socio-cultural. Implementation of those indications seems quite feasible in the case of recreational areas which are being developed. A much more difficult task is to adapt the already existing places which are particularly popular among tourists, in a way that would make them compatible with the demands of sustainable development. More effort should also be put into revitalization activities as well as into reconstruction and restoration of balance in areas devastated by unsustainable tourism. As noticed by, among others, M. Kazimierczak, lack of sustainability in the sphere of tourism manifests itself in such phenomena as tourism traffic overload, which leads to the destruction of the natural and cultural environment, including progressive deculturation and associated loss of socio-cultural identity, which is accompanied by alienation (Kazimierczak 2010: 9).

L. Frändberg provided an analysis of the impact of tourism on the environment highlighting, among others, continuing consumption of natural resources at the place of their location, in the tourist area, and the related decrease in the value of the offered product due to its reduced natural value. In the considered perspective there is, therefore, a close cause and effect relationship, because tourism, by the fact that it affects both quantitatively and qualitatively the natural environment, in a sense limits not only the availability of products in their original form, but also the demand for the offered service (Frändberg 2005: 278 ).

Unsustainable tourism resulting from anthropopressure is noticeable in many areas both in Poland and in Slovakia. Even if the state of changes in the natural environment resulting from human presence is objectively verified, the criteria for their assessment are subjective and often dependent on social decisions. The example of tourism confirms the increasingly popular opinion that problems of the natural environment are also social problems (Ludwig, Hilborn, Walters 1993: 36).

These, in turn, can be eliminated, and certainly neutralized, referring to the heritage of ethics (including, among others, tourism ethics) and axiology associated with education, as tools of effective implementation of the principles of sustainable development and spatial order into tourism, but also, and perhaps first and foremost, as an apparatus which makes it possible to demonstrate that the abovementioned principles underlie the idea of a sustainable tourism. However, as noted by, among others T. Borys, it is not the question of a persistent state of specific social schizophrenia that is particularly visible in the abundance of declarative slogans regarding responsibility, solidarity, equitability (including fair redistribution of goods and services in the field of tourism), social trust 
or even justice, which ultimately nobody from among those even who are endowed with narrow instrumental awareness, wants to implement (Borys 2009). The outlined attitude may be changed when we provide proper justification for the need to abandon the present mindsets, which are inherently narrow-range and often selfish, and to indicate why it is worthwhile to implement the idea of sustainable tourism.

To this end, proponents of incorporating ethics (Kazimierczak 2010: 13) and axiology in the process of implementing sustainable tourism postulates, point to an urgent need to indicate the goals and directions of its development and, at the same time, to elaborate an ethical and axiological compendium of knowledge about their proper implementation, or the methods of proper conduct in the field of sustainable tourism. More broadly, to show the ethical and axiological basis for the proper implementation of the idea of sustainable tourism.

Among these goals and directions, special attention should be paid to, among others

- respect for and protection of human rights (including tourists and host communities),

- elimination of child prostitution and exploitation of child labor,

- improving the quality of life and quality of education, as well as working conditions in the tourism industry,

- fair distribution of the economic benefits of tourism,

- inclusion (integration) and the possibility of co-shaping the local community,

- protection and support of culture, national identity and landscape aesthetics,

- free access to the natural and social wealth of the region.

The ethics and the related axiology may serve to explain the need to implement the abovementioned goals, since they provide tools for formulating arguments, organizing, explaining and emphasizing the role and significance of the assumptions underlying all kinds of legal documents, or plans to implement sustainable tourism in local and global understanding. What is more, they should help in strengthening social (including individual) attitudes within the framework of (morally) proper behavior. Although, it is still problematic to find an unequivocal answer to the question about the underlying tasks of ethics or axiology in the order of the necessity and sequence of their explanation, they both are not only successfully dealing with the explanation of the goals and directions towards which sustainable tourism should head, but also define them against the key models of resolving ethical and axiological disputes, i.e. as part of the ethical model of duty, moral virtues, utility and moral laws. ${ }^{3}$ Each of the mentioned models of applied ethics proves their a significant effectiveness in solving the dilemmas presented in the article and which are generated by sustainable tourism, giving conclusive and, what is important, unambiguous indications. Both the ethics of duty (regardless of its source), ethics of virtues (in the order of knowledge), ethics of utility (turned towards the consequences of our actions), and finally, the ethics of moral laws, distinguish the common goods (human values), which should provide us with guidance in the realization of our goals, or postulates of a sustainable tourist in the economic, socio-cultural and historical perspective, taking into account the vital needs of the natural environment.

The obvious need to implement sustainable tourism finds its justification not only in scientific facts (in the area of, among others, economic sciences and management, or even spatial planning), but also in ethical indications based on axiology, including the axiology of sustainable development. The above-mentioned models of ethics provide a framework within which we can analyze

3 A broader discussion of practical ethics in the key models of their occurrence is presented in the article: A. Klimska, M. Leźnicki, Etyczno-aksjologiczne przesłanki Agendy na Rzecz Zrównoważonego Rozwoju 2030 (Agendy post-2015), Zeszyty Naukowe PŚ “Organizacja i Zarządzanie” 106/2017. 
and look for the best ways to deal with the threats that are generated by the rapid changes taking place in tourism. These, in turn, can and usually have a multifaceted nature, scope of impact and intensity, including their forcefulness and invasiveness, and finally, the addressee, who on the one hand can be a human being, and on the other, in the wider context, the natural environment.

Finally, it is worth noting that abandonment or failure to include ethical and axiological reflection in the face of dynamic development of sustainable tourism, as noted by, among others A. Klimková, will, and certainly can, generate, numerous threats, i.e.:

- if the cultural and natural heritage which embodies the local traditional values is not sustained, or if resources are not used in a sustainable way balancing production and consumption, we will not be able to conserve and further build the social cohesion of the community;

- we will lose the traditional skills and abilities which may result in alienation, loss of solidarity, increasing poverty and injustice in the region;

- $\quad$ in times of crisis we will not be able to help the people experience continuity, protect their dignity, support reciprocity, common values and mutual respect between different groups which represent the preconditions for harmonic development of the society and elimination of unwanted pathological phenomena (hostility, violence, xenophobia, discrimination, addiction, etc.).

- a number of researches have shown that companies as well as regions are at risk if their leaders do not understand that ethical leadership is an important part of effective and responsible management. If there is no ethical leadership, there is no space or ability to solve the basic problems of ethical responsibility, social responsibility, ecological responsibility or environmental (in)justice;
- lack of ethical leadership in the region, as shown by recent experience, results in the lack of access to resources and participative decision-making. Evaluation of ethical policies and strategies is an important precondition for trustworthiness and good reputation which further creates investment opportunities for supporting projects that will help the region to develop (Klimková 2017).

\section{Conclusion}

The present article, after a brief discussion of what sustainable tourism is and when it emerged, taking into account the tasks, objectives and assumptions underlying its foundations, and emphasizing its multidisciplinary and sustensive character, has elucidated two distinctive, although undeniably not sole, aspects in which the concept's significance is discussed in Poland and Slovakia. In the first case, it was discussed in the perspective of the dynamically developing sustainable spatial economy understood in the article broadly, i.e. as spatial planning, spatial management and spatial development. At the same time, the author took into account the three-dimensional dependencies at the point of convergence between design, implementation and the state of spatial order. In the case of Slovakia, the importance of cultural heritage has been emphasized as an important element of sustainable tourism development with an indication of its considerable complexity, including dependence on tradition, cultural specificity, remembrances (memory), identity policy and others. However, both in the case of Poland and Slovakia, whether discussing the issue of spatial planning, which should underlie the practical implementation of the idea of sustainable tourism or cultural heritage, which should undoubtedly be taken into account when implementing sustainable tourism, it still remains, as has been emphasized in the article, unsustainable. Excessive anthropopressure has a serious impact on the existing situation. Axiology has been indicated as an effective tool for 
implementing the principles of sustainable development into tourism, and at the same time a remedy for anthropopressure. In the further part of the text, the author has presented the key areas of incorporating axiology and the related ethics in the process of not only explaining or arguing, but of proper implementation of the objectives and directions in which sustainable tourism should develop, taking into account the economic, ecological (bearing in mind welfare of the natural environment) and socio-cultural dimensions. What is important, the aforementioned axiology and the related ethics do not impose, but point to and explain the proper ways of proceeding, and thus strive to increase social self-knowledge, to understand and develop collective consciousness, for which knowledge correlated with values is of strategic importance. Principles and values proclaimed within its framework, as in the case of the value of life, justice, identity (including cultural identity), responsibility, equality, or freedom, are not of exclusive, but common or universal character.

What is more, the axiology for sustainable tourism quoted in the article is also a tool that can be used to argue, organize, explain and highlight the role and significance of the assumptions underlying any legal documents, action plans or specific guidelines, as, among others, in the case of recommendations contained in the Post-2015 Agenda, European Landscape Convention, proclaimed in Poland (under the Resolution of the Council of Ministers No. 143/2015) Program for Tourism Development, Slovak Nature and Landscape Protection Acts and Construction Law (Acts No. 50/1976 Zb.U. and 543/2002 Zb.U) and others.

\section{References}

Borys T., 2009, Problemy edukacji dla zrównoważonego rozwoju - perspektywa aksjologiczna, in: Janikowski R., Krzysztofek K. (eds), „Kultura a zrównoważony rozwój: środowisko - ład przestrzenny - dziedzictwo", UNESCO, Warszawa.

Chan J.K.L., 2010, Building sustainable tourism destination and developing responsible tourism: conceptual framework, key issues and challenges, Tourism Development Journal- An International Research Journal, Vol 8(1), 24-32.

Dębski J., 2001, Gospodarka przestrzenna - jej geneza, stan i rozwój. Tom 1. Wydawnictwo Wyższej Szkoły Finansów i Zarządzania, Białystok.

Dubravská, M., Širá, E., 2015, The analysis of the factors influencing the international trade of the Slovak Republic, in: Procedia economics and finance. Vol. 23 DOI:10.1016/S2212-5671(15)oo569-9.

Fennell D. A., 2008, Ecotourism, Routledge.

Frändberg L., 2005, Tourism as Victim. Problem or Solution: Story Lines of a Complex Industry - Environment Relation, in: Hall C. M., Higham J. E. S. (eds), Tourism, Recreation, and Climate Change, Channel View Publication, Tonawanda, NY.

Ireland T., Schofield J., 2015, The Ethics of Cultural Heritage. Springer: e-book. DOI 10.1007/978-1-4939-1649-8.

Kazimierczak M., 2010, Jaka aksjologie zakłada idea zrównoważonego rozwoju w turystyce? in: Młynarczyka Z, Potockiej I., Zajadacz A., „Uwarunkowania i plany rozwoju turystyki”, Tom VI, Turystyka zrównoważona, Bogucki Wydawnictwo Naukowe, Poznań, 9-18.

Klimková A., 2017, Ethical counseling and New horizons of the social dimensions of Sustainability and cultural heritage in: Scientific Papers of Silesian University of Technology. Organization and Management Series: Vol 106 DOI http://dx.doi. org/10.29119/1641-3466.2017.106.20.

Klimska A., Leźnicki M., 2017, Etyczno-aksjologiczne przesłanki Agendy na Rzecz Zrównoważonego Rozwoju 2030 (Agendy post-2015), Zeszyty Naukowe PŚ „Organizacja i Zarządzanie” 106/2017: 165-181. Kozikowska M., 2013, Zrównoważony rozwój a turystyka w Polsce, Zeszyty Naukowe Turystyka i Rekreacja 11 (1): 47-65.

Ludwig D., Hilborn R., Walters C., 1993, Uncertainty, resource exploitation, and conservation: lessons from history, Science, Vol. 260, No. 5104: 17-36.

Matlegiewicz M., 2009, Ekoturystyka jako przyjazna środowisku forma turystyki, in: Folia Pomeranae Universitatis Technologiae Stetinensis. Folia Pomer. Univ. Technol. Stetin., Oeconomica 275 (57:59-66.

Meyer B., 2008, Historyczne i wspótczesne czynniki determinujace rozwój turystyki, Zeszyty Naukowe 
Uniwersytetu Szczecińskiego. Ekonomiczne Problemy Turystyki, No 521/11: 205-217.

Meyer B., 2008, Ład przestrzenny jako rezultat $i$ determinanta rozwoju turystyki, in: Wodejko S. (eds), „Zrównoważony rozwój turystyki”, Szkoła Główna Handlowa w Warszawie- Oficyna Wydawnicza, Warszawa: 59-69.

Meyer B., 2009, Ksztattowanie przestrzeni przez turystyke, Ekonomiczne Problemy Turystyki, Zeszyty Naukowe Uniwersytetu Szczecińskiego, Vol. 12: 193-205.

Ministerstwo Sportu i Turystyki, 2015, Program Rozwoju Turystyki do 2020 roku, Warszawa.

Niezgoda A., 2006, Obszar recepcji turystycznej $w$ warunkach rozwoju zrównoważonego, Wydawnictwo Akademii Ekonomicznej w Poznaniu, Poznań.

Niezgoda A., 2008, Turystyka zrównoważona - istota, zasady i kryteria koncepcji, in: Wodejko S. (eds), „Zrównoważony rozwój turystyki”, Szkoła Główna Handlowa w Warszawie- Oficyna Wydawnicza, Warszawa: 83-93.

Parysek J. J., 2006, Wprowadzenie do gospodarki przestrzennej, Wyd. Nauk. UAM, Poznań.

Patterson C., 2016, Sustainable tourism: Business Development, Operations, and Management, Human Kinetics Publishers.

Ricouer P., 1999, Memory and Forgetting, in: Keaney R., Dooley M. (eds.), "Questioning ethics”, 30 Contemporary debates in philosophy. Routledge, Oxford: 5-11.

Rozzi R. et al. (eds.) 2013, Linking Ecology and Ethics for a Changing World: Values, 9
Philosophy, and Action, Ecology and Ethics 1, DOI 10.1007/978-94-007-7470-4_2.

Šimková E., 2013, Sustainability in Tourism and Rural Areas. Gaudeamus Univerzita Hradec Králové.

Širá E., 2015, Slovak food processing industry in the context of globalisation and integration tendencies, Polish journal of management studies, Vol. 11, no. 1. Sofield T., De Lacy T., Lipman G., Daugherty S., 2004, Sustainable Tourism Eliminating Poverty (St Ep). An Overview, CRC for Sustainable Tourism Pty Ltd.

UNESCO, 2015, Culture in the Post-2015 Sustainable Development Agenda.

Wearing S., Neil J., 1999, Ecotourism. Impacts, potentials and possibilities, $\mathrm{BH}$.

Weaver D. B., 2001, Ecotourism in the Context of Other Tourism Types, in: Weaver D. B. (eds), „The Encyclopedia of Ecotourism", Published Wallingford: CABI Pub, 73-83.

Zaręba D., 2006, Ekoturystyka. Wyzwania i nadzieje, Wydawnictwo Naukowe PWN, Warszawa.

Web-o1: www2.unwto.org/content/who-we-are-o (access: 20.01.2018).

Web-o2: https://www.gstcouncil.org/about/about-us/ (access: 17.12.2017).

Web-o3: http://www2.unwto.org/event/eleventh-meeting-committee-tourism-and-sustainability (access: 20.01.2018).

Web-04: http://www.un.org/sustainabledevelopment/cities/ (access: 17.12.2017).

Web-05: https://www.globeseries.com/forum2012/ media/216/globe_199o_review.pdf (access: 10.11.2017).

\section{Podstawy aksjologii dla zrównoważonej turystyki}

\section{Streszczenie}

Artykuł porusza kwestię zrównoważonej turystyki w Polsce i na Słowacji, podkreślając jej znaczenie, a także cele i zadania. Sytuację turystyki w Polsce przedstawiono w odniesieniu do zagadnień gospodarki przestrzennej, podczas gdy przykład słowacki koncentruje się głównie na znaczeniu dziedzictwa kulturowego. Oba powiązane ze sobą aspekty uznano za kluczowe dla rozwoju zrównoważonej turystyki. Wskazując na zauważalnie niezrównoważony charakter współczesnej turystyki, autorzy podkreślili pilną potrzebę odwoływania się do argumentów etycznych i aksjologicznych w procesie wdrażania zasad zrównoważonego rozwoju i ładu przestrzennego do turystyki.

\section{Slowa kluczowe}

zrównoważona turystyka, aksjologia, gospodarka przestrzenna, dziedzictwo kulturowe 